\title{
PENGARUH PRODUK DOMESTIK REGIONAL BRUTO (PDRB) TERHADAP KREDIT BERMASALAH PADA BANK UMUM DI JAWA BARAT PERIODE 2012-2017
}

\author{
Hasan Fahmi Kusnandar \\ Politeknik Triguna Tasikmalaya \\ hasanfahmi2kusnandar@gmail.com \\ Elin Rahmawati \\ Politeknik Triguna Tasikmalaya \\ rahmawatielin@gmail.com \\ Maman Sulaeman \\ Politeknik Triguna Tasikmalaya \\ mansulaeman1274@gmail.com
}

\begin{abstract}
Abstrak - Penelitian ini bertujuan untuk menganalisis mengenai Pengaruh Produk Domestik Regional Bruto (PDRB) Terhadap Kredit Bermasalah pada Bank Umum di Jawa Barat Periode 2012-2017. Metode penelitian yang digunakan adalah metode deskriptif dan verifikatif. Metode verifikatif yang digunakan adalah analisis regresi linear sederhana. Teknik pengumpulan data yang digunakan adalah studi kepustakaan dan dokumentasi sedangkan jenis data yang digunakan adalah data sekunder, yaitu data yang diperoleh dari Laporan publikasi Badan Pusat Statistik (BPS) Jawa Barat mengenai Produk Domestik Regional Bruto (PDRB) dan Laporan publikasi Otoritas Jasa Keuangan (OJK) mengenai Statistik Perbankan Indonesia. Hasil penelitian ini menunjukkan Produk Domestik Regional Bruto (PDRB) memiliki pengaruh positif signifikan terhadap Kredit Bermasalah pada Bank Umum di Jawa Barat periode 2012-2017.
\end{abstract}

Kata Kunci: Produk Domestik Regional Bruto (PDRB), Kredit Bermasalah

ABSTRACT - This research was aimed to analyze about influence Product Domestic Regional Bruto (PDRB) to problem loans of commercial banks at West Java 20122017 period. This research methods used descriptive and verificative methods. The verificative methods used simple linear regression analysis. Data collecting techniques are documentation and literature studies. Data type used secondary data wich obtained from publication report of West Java BPS-Statistics Indonesia about Product Domestic Regional Bruto (PDRB) and publication report of Financial Services Authority about Indonesia Banking Statistics. The results showed that the Product Domestic Regional Bruto (PDRB) had a significant positive effect on problem loans of commercial banks at West Java 2012-2017 period.

Keyword: Product Domestic Regional Bruto (PDRB), Non Performing Loan 


\section{PENDAHULUAN}

Dalam dunia modern sekarang ini, peranan perbankan dalam memajukan perekonomian suatu negara sangatlah besar. Hampir semua sektor yang berhubungan dengan berbagai kegiatan keuangan selalu membutuhkan jasa bank. Oleh karena itu, saat ini dan dimasa yang akan datang kita tidak akan lepas dari dunia perbankan jika hendak menjalankan aktivitas keuangan, baik perorangan maupun lembaga, baik sosial atau perusahaan (Kasmir, 2013:3). Kegiatan usaha yang dilakukan oleh Bank Umum sesuai ketentuan UndangUndang Nomor 10 tahun 1998 salah satunya meliputi pemberian pinjaman dalam bentuk kredit.

Dalam melakukan kegiatan utamanya sebagai penyalur kredit bank diharuskan berhati-hati dalam memberikan kredit kepada calon debitur, bagi bank hal ini penting agar dana yang dikucurkan tidak mengalami kerugian atau bermasalah. Menurut Mulyati (2016:77) "kredit yang diberikan bank mengandung banyak risiko sehingga dalam pelaksanaannya bank harus memperhatikan asas-asas perkreditan yang sehat".

Menurut Peraturan Bank Indonesia Nomor 15/12/PBI/ 2013, risiko kredit adalah "risiko akibat kegagalan debitur dan atau pihak lain dalam memenuhi kewajiban kepada bank". Sedangkan pengertian kredit bermasalah menurut Sutojo (2008:13) adalah "suatu kondisi dimana debitur mengingkari janji mereka membayar bunga dan atau kredit induk yang telah jatuh tempo, sehingga terjadi keterlambatan atau sama sekali tidak ada pembayaran".

Terjadinya kredit bermasalah pada suatu bank dapat mempengaruhi tingkat kesehatan bank tersebut dikarenakan terjadinya penurunan kualitas kredit. Selain disebabkan oleh beberapa faktor internal dan eksternal, penurunan kualitas kredit juga dapat disebabkan oleh kondisi perekonomian yang memburuk seperti yang dikutip oleh Taswan (2010:451), "Penurunan kualitas kredit juga bisa disebabkan oleh kondisi perekonomian yang semakin memburuk. Kondisi ekonomi yang memburuk akan berdampak pada bisnis para debitur. Misalnya inflasi yang tinggi, maka dapat diduga bahwa daya beli masyarakat turun. Penurunan daya beli ini berakibat pada penurunan penjualan. Penurunan penjualan berarti penurunan arus kas yang pada gilirannya mempengaruhi kemampuan membayar angsuran kredit. Pembayaran angsuran yang semakin tidak tepat, menimbulkan kualitas kredit semakin buruk bahkan terjadilah kredit macet".

Berdasarkan uraian diatas maka dapat ditarik kesimpulan bahwa perekonomian suatu daerah mampu mempengaruhi kualitas pembayaran kredit di wilayah/daerah tersebut. Ketika pendapatan masyarakat di suatu daerah meningkat, maka perekonomian daerah atau Produk Domestik Regional Bruto (PDRB) di wilayah/daerah tersebut juga akan meningkat, sehingga dapat meningkatkan kemampuan masyarakat dalam membayar kembali pinjamannya kepada bank (Fiermansyah, 2014).

Menurut Badan Pusat Statistik (2017:3), "Produk Domestik Regional Bruto (PDRB) merupakan salah satu indikator penting untuk mengetahui kondisi ekonomi di suatu wilayah/regional dalam suatu periode tertentu, baik atas harga berlaku maupun atas dasar harga konstan". Adapun menurut Sjafrizal (2014:181), "Produk Domestik Regional Bruto (PDRB) merupakan indikator penting yang digunakan untuk mengetahui kondisi ekonomi provinsi tertentu. Pada dasarnya PDRB merupakan data dan 
informasi dasar tentang kegiatan ekonomi suatu daerah".

Menurut Nasution dan Doddy (2007:42), "ketika Gross Domestic Product (GDP) meningkat, secara teori terjadi peningkatan transaksi ekonomi, dunia bisnis menggeliat, sehingga Non Performing Loan (NPL) turun". Meningkatnya perekonomian nasional tentunya tidak terlepas dari sumbangasih setiap daerah, salah satunya Jawa Barat. Provinsi Jawa Barat dibentuk pada tahun 1925 oleh Hindia Belanda dan mulai bergabung menjadi bagian dari Republik Indonesia pada tanggal 17 Agustus 1945.

Sejak awal pembentukannya, provinsi Jawa Barat telah melalui berbagai perkembangan, salah satunya yaitu dengan bertambahnya jumlah bank umum yang berada di wilayah Jawa Barat. Dengan banyaknya bank umum yang tersebar di berbagai wilayah di Jawa Barat sekarang ini, tentunya tidak terlepas dari adanya risiko kredit yang akan dihadapi oleh bank umum tersebut.

Berikut penulis sajikan tabel data Kredit Bermasalah pada Bank Umum di Jawa Barat tahun 2012-2017 :

Tabel 1. Kredit Bermasalah Pada Bank Umum di Jawa Barat Periode 2012-2017 (Dalam Milyar $\mathrm{Rp})$

\begin{tabular}{|c|c|}
\hline Tahun & $\begin{array}{c}\text { Kredit } \\
\text { Bermasalah }\end{array}$ \\
\hline 2012 & 5.318 \\
\hline 2013 & 6.833 \\
\hline 2014 & 8.094 \\
\hline 2015 & 8.724 \\
\hline 2016 & 12.932 \\
\hline 2017 & 14.625 \\
\hline
\end{tabular}

Sumber : (Otoritas Jasa Keuangan)

Berdasarkan tabel 1.1 dapat dilihat bahwa kredit bermasalah pada Bank Umum di Jawa Barat dari tahun 2012 sampai 2017 cenderung mengalami kenaikan.
Penelitian mengenai faktor-faktor penyebab terjadinya kredit bermasalah telah dilakukan oleh peneliti-peneliti sebelumnya, salah satunya penelitian yang dilakukan oleh Arifandi, (2017) Dimana hasil dari penelitian tersebut menunjukkan bahwa PDRB berpengaruh signifikan terhadap NPL.

Penelitian Fiermansyah (2014) juga menemukan bahwa faktor penentu dari NPL adalah PDRB. Namun berbeda dengan temuan Yunis (2008) yang menjelaskan Perbandingan Faktor Penyebab Timbulnya NPL dan NPF Pada Perbankan Konvensional dan Syariah di Indonesia adalah karena factor capital yang dimiliki nasabah.

Berdasarkan latar belakang di atas terlihat adanya gap mengenai faktor eksternal yang berpengaruh terhadap kredit bermasalah, maka penulis akan melakukan penelitian dengan mengangkat tema yang berdasarkan pada latar belakang tersebut dengan judul "Pengaruh Produk Domestik Regional Bruto (PDRB) Terhadap Kredit Bermasalah Pada Bank Umum Di Jawa Barat Periode 2012-2017".

\section{Rumusan Masalah}

Berdasarkan latar belakang masalah di atas, maka pokok permasalahan yang akan dirumuskan dalam penelitian ini adalah sebagai berikut :

1. Bagaimana Produk Domestik Regional Bruto (PDRB) Jawa Barat periode 2012-2017?

2. Bagaimana Kredit Bermasalah pada Bank Umum di Jawa Barat periode 2012-2017?

3. Bagaimana pengaruh Produk Domestik Regional Bruto (PDRB) terhadap Kredit Bermasalah pada Bank Umum di Jawa Barat periode 2012-2017? 


\section{Tujuan Penelitian}

Adapun tujuan peneliti dalam melakukan penelitian adalah sebagai berikut:

1. Untuk mendapatkan hasil kajian mengenai Produk Domestik Regional Bruto (PDRB) Jawa Barat periode 2012-2017.

2. Untuk mendapatkan hasil kajian mengenai Kredit Bermasalah pada Bank Umum di Jawa Barat periode 2012-2017.

3. Untuk mendapatkan hasil pengujian mengenai Pengaruh Produk Domestik Regional Bruto (PDRB) Terhadap Kredit Bermasalah Pada Bank Umum di Jawa Barat periode 2012-2017.

\section{KAJIAN LITERATUR}

\section{Produk Domestik Regional Bruto (PDRB)}

Menurut Badan Pusat Statistik (2017:3), "salah satu indikator penting untuk mengetahui kondisi ekonomi di suatu wilayah/regional dalam suatu periode tertentu adalah data Produk Domestik Regional Bruto (PDRB), baik atas harga berlaku maupun atas dasar harga konstan". PDRB atas dasar harga berlaku menggambarkan nilai tambah barang dan jasa yang dihitung menggunakan harga yang berlaku pada setiap tahun. Sedangkan PDRB atas dasar harga konstan menunjukkan nilai tambah barang dan jasa yang dihitung menggunakan harga yang pada suatu tahun tertentu sebagai dasar. PDRB menurut harga berlaku digunakan untuk melihat pergeseran serta struktur ekonomi. Sementara itu, PDRB konstan digunakan untuk mengetahui pertumbuhan ekonomi pada suatu periode ke periode (tahun ke tahun atau triwulan ke triwulan).

Menurut Badan Pusat Statistik (2017:3), terdapat 3 (tiga) pendekatan yang biasanya digunakan dalam menghitung angka-angka PDRB, yaitu:

1. Menurut Pendekatan Produksi Menurut pendekatan ini, PDRB adalah jumlah nilai tambah atas barang dan jasa yang dihasilkan oleh berbagai unit produksi di wilayah suatu negara dalam jangka waktu tertentu (biasanya satu tahun).

2. Menurut Pendekatan Pendapatan PDRB menurut pendekatan ini merupakan jumlah balas jasa yang diterima oleh faktor-faktor produksi yang ikut serta dalam proses produksi disuatu negara dalam jangka waktu tertentu (biasanya satu tahun). Balas jasa faktor produksi yang dimaksud adalah upah dan gaji, sewa tanah, bunga modal dan keuntungan; semuanya sebelum dipotong pajak penghasilan dan pajak langsung lainnya. Dalam definisi ini, PDRB mencakup juga penyusutan dan pajak tidak langsung neto (pajak atas produksi dan impor dikurangi subsidi).

3. Menurut Pendekatan Pengeluaran PDRB adalah semua komponen permintaan akhir yang terdiri dari: (1) pengeluaran konsumsi akhir rumah tangga (2) pengeluaran konsumsi akhir lembaga non profit yang melayani rumah tangga (3) pengeluaran konsumsi akhir pemerintah (4) pembentukan modal tetap domestik bruto (5) perubahan inventori, dan (6) ekspor neto (ekspor dikurangi impor).

\section{Perhitungan PDRB}

Menurut Badan Pusat Statistik (2017:4), "PDRB pengeluaran menjelaskan penggunaan dari sebagian besar Produk Domestik Regional Bruto 
(PDRB) untuk memenuhi kebutuhan konsumsi akhir, atau dengan istilah yang berbeda disebut sebagai ouput akhir". Mengkaitkan antara pendapatan dan pengeluaran untuk pembelian barang dan jasa dari produk domestik maupun impor (termasuk untuk diekspor) merupakan bentuk analisis yang sederhana dari data PDRB.

Adapun model pendekatan PDRB menurut pengeluaran secara simultan menurut Badan Pusat Statistik (2018:6) dapat ditunjukkan melalui model atau persamaan Keynesian sbb:

$$
\begin{aligned}
& \mathrm{Y}=\mathrm{C}+\mathrm{GFCF}+\Delta \text { Invetori }+(\mathrm{X}-\mathrm{M}) \\
& \text { Sumber: (Badan Pusat Statistik, 2018:6) }
\end{aligned}
$$

Keterangan :

$Y($ income $)=P D R B$

$\mathrm{C}($ Consumption $)=$ Konsumsi Akhir

GFCF (Gross Fixed Capital Formation) = Pembentukan Modal Tetap Bruto

$\Delta$ inventori $=$ Perubahan Inventori

$\mathrm{X}=$ Ekspor

$\mathrm{M}=$ Impor

Menurut Badan Pusat Statistik (2017:9), berikut adalah komponenkomponen dari Produk Domestik Regional Bruto (PDRB) menurut pengeluaran:

1. Pengeluaran Konsumsi Akhir Rumah Tangga (PKRT)

Pengeluaran Konsumsi Akhir Rumah Tangga (PKRT) adalah pengeluaran atas barang dan jasa oleh rumah tangga untuk tujuan konsumsi.

2. Pengeluaran Konsumsi Akhir LNPRT

LNPRT merupakan lembaga yang melayani anggotanya atau rumah tangga, serta tidak dikontrol oleh pemerintah. Sektor ini berperan dalam menyediakan barang dan jasa bagi anggotanya maupun bagi rumah tangga secara gratis atau pada tingkat harga yang tidak berarti secara ekonomi.

3. Pengeluaran Konsumsi Akhir Pemerintah

Dalam suatu perekonomian, unit pemerintah bisa berperan sebagai konsumen maupun produsen, serta sebagai regulator yang menetapkan berbagai kebijakan di bidang fiskal dan moneter. Sebagai konsumen, pemerintah akan melakukan aktivitas konsumsi atas barang dan jasa akhir. Sedangkan sebagai produsen, pemerintah akan melakukan aktivitas memproduksi barang dan jasa maupun aktivitas investasi.

4. Pembentukan Modal Tetap Bruto (PMTB)

PMTB didefinisikan sebagai penambahan dan pengurangan aset tetap pada suatu unit produksi dalam kurun waktu tertentu. PMTB erat kaitannya dengan keberadaan aset tetap (fixed asset) yang dilibatkan dalam proses produksi. Penambahan barang modal mencakup pengadaan, pembuatan, pembelian, sewa beli (financial leasing) barang modal baru dari dalam negeri serta barang modal baru dan bekas dari luar negeri, dan pertumbuhan aset sumber daya hayati yang dibudidaya.

5. Perubahan Inventori

Dalam aktivitas ekonomi, inventori berfungsi sebagai salah satu komponen yang dibutuhkan untuk keberlangsungan proses produksi, di samping tenaga kerja dan barang modal. Dalam PDB/PDRB, komponen Perubahan Inventori merupakan bagian dari Pembentukan Modal Bruto, atau yang lebih dikenal sebagai 
investasi fisik yang terjadi pada kurun waktu tertentu di dalam suatu wilayah. Inventori (persediaan) adalah barang yang dikuasai oleh produsen untuk tujuan diolah lebih lanjut menjadi barang dalam bentuk lain yang mempunyai nilai ekonomi maupun nilai manfaat yang lebih tinggi.

6. Ekspor-Impor

Ekspor-Impor di suatu wilayah didefinisikan sebagai alih kepemilikan ekonomi (baik penjualan/pembelian, barter, hadiah ataupun hibah) atas barang dan jasa antara residen wilayah tersebut dengan nonresiden yang berada di luar wilayah tersebut.

\section{Risiko Kredit}

Menurut Peraturan Bank Indonesia Nomor 15/12/PBI/ 2013, risiko kredit adalah "risiko akibat kegagalan debitur dan atau pihak lain dalam memenuhi kewajiban kepada bank".

Adapun menurut Fahmi (2011:18) "risiko kredit merupakan bentuk ketidakmampuan suatu perusahaan, institusi, lembaga maupun pribadi dalam menyelesaikan kewajiban-kewajibannya secara tepat waktu baik pada saat jatuh tempo maupun sesudah jatuh tempo dan itu semua sesuai dengan aturan dan kesepakatan yang berlaku".

\section{Kredit Bermasalah}

Menurut Ikatan Bankir Indonesia (2015:91) ada beberapa pengertian kredit bermasalah, yaitu :

1. Kredit yang dalam pelaksanaannya belum mencapai/memenuhi target yang diinginkan bank.

2. Kredit yang memiliki kemungkinan timbulnya risiko dikemudian hari bagi bank dalam arti luas.

3. Mengalami kesulitan didalam penyelesaian kewajiban-kewajiban, baik dalam bentuk pembayaran kredit kembali pokoknya dan atau pembayaran bunga, denda keterlambatan, serta ongkos-ongkos bank yang menjadi beban debitur.

4. Kredit golongan perhatian khusus, kurang lancar, diragukan, dan macet serta golongan lancar yang berpotensi menunggak.

\section{Faktor-Faktor Penyebab Kredit Bermasalah \\ Menurut Taswan (2010:467) faktor-} faktor penyebab terjadinya kredit bermasalah ada 2 (dua) faktor, yaitu :

1. Faktor internal

Kurang tajamnya analisis kredit. Pada tahap analisis kredit ini bank seharusnya mampu mengungkapkan hal-hal yang berkaitan dengan usaha calon debitur Sistem pengawasan dan administrasi kredit. Tidak dimilikinya sistem pengawasan dan administrasi kredit yang tertib menyebabkan manajemen tidak dapat memantau penggunaan kredit dan perkembangan usahanya, sehingga manajemen tidak dapat melakukan tindakantindakan koreksi dengan segera bila ditemukan penyimpanganpenyimpangan.

2. Faktor eksternal

Faktor persaingan yang sangat ketat, debitur kurang mampu menghadapi persaingan karena kualitas barang yang dihasilkan buruk, harga kurang bersaing, distribusinya buruk, promosinya tidak tepat, dan lain-lain.

Keadaan perekonomian yang tidak mendukung perkembangan usaha debitur.

Penggunaan kredit diluar objek pembiayaan. Ini sering terjadi pada debitur yang tidak hati-hati. Misalnya 
kredit untuk usaha, digunakan untuk pembelian mobil pribadi.

\section{Penyelesaian Kredit Bermasalah}

Menurut Ikatan Bankir Indonesia (2015:95), "penyelamatan kredit bermasalah adalah serangkaian tindakan yang dapat dilakukan bank terhadap debitur bermasalah untuk dapat memperbaiki kinerja usaha debitur yang bersangkutan dan kualitas kreditnya, yang didasarkan atas hasil analisis bank, debitur tersebut masih mempunyai prospek terkait aktivitas usaha yang dijalaninya dan dapat melaksanakan kewajibannya kepada bank sehingga dapat menjaga kepentingan bank dan melindungi bank dari potensi risiko yang lebih besar".

Adapun tindakan yang dapat dilakukan bank dalam penyelamatan kredit bermasalah menurut Ikatan Bankir Indonesia (2015:95), antara lain sebagai berikut:

1. Rescheduling (penjadwalan ulang) Rescheduling yaitu perubahan syarat kredit hanya menyangkut jadwal pembayaran dan atau jangka waktu termasuk masa tenggang dan perubahan besarnya angsuran.

2. Reconditioning (persyaratan ulang) Reconditioning ialah perubahan sebagian atau seluruh syarat kredit yang tidak terbatas pada perubahan jadwal pembayaran, jangka waktu, tingkat suku bunga, penundaan pembayaran sebagian atau seluruh bunga dan persyaratan lainnya.

3. Restructuring (restrukturisasi)

Upaya penyelamatan dengan melakukan perubahan syaratsyarat kredit yang menyangkut penambahan dana bank, konversi seluruh atau sebagian tunggakan bunga menjadi pokok kredit baru atau konversi seluruh atau sebagian dari kredit menjadi equity (modal) perusahaan dan equity bank, yang dilakukan dengan atau tanpa rescheduling atau reconditioning.

4. Manajemen Assistancy

Manajemen Assistancy yaitu bantuan konsultasi dan manajemen profesional yang diberikan bank pada nasabah yang masih mampu. Jika kondisi nasabah tidak membaik sesuai dengan yang diharapkan pada langkah penyelamatan, maka dapat dipertimbangkan tindakan penyelesaian kredit bermasalah.

5. Debt to Equity Swap

Terkait dengan perbankan (khususnya perkreditan), debt to equity swap merupakan kegiatan penyertaan modal sementara dalam rangka penyelamatan kredit dalam bentuk penyertaan modal oleh bank pada perusahaan debitur untuk mengatasi kegagalan kredit, yaitu dengan mengubah utang debitur menjadi penyertaan modal bank pada perusahaan debitur.

\section{METODE PENELITIAN}

Metode penelitian yang digunakan oleh peneliti yaitu metode penelitian deskriptif dan verifikatif, diharapkan metode penelitian tersebut dapat memberikan gambaran maupun deskripsi secara sistematis dan akurat mengenai hubungan antar fenomena yang diselidiki oleh penulis.

\section{Jenis Dan Sumber Data}

Dalam penelitian ini data yang digunakan adalah data sekunder. Menurut Wijaya (2013:19), "data sekunder yaitu data yang diperoleh dari sumber yang menerbitkan dan bersifat siap pakai”. 


\section{Teknik Pengumpulan Data}

Adapun teknik pengumpulan data yang dilakukan penulis antara lain:

1. Studi Kepustakaan

2. Dokumentasi

\section{Operasional Variabel}

Adapun variabel penelitian yang digunakan oleh penulis menurut Sugiyono (2016:4) adalah:

1. Variabel independent (X). Yang menjadi variabel independent (bebas) dalam penelitian ini adalah Produk Domestik Regional Bruto (PDRB).

2. Variabel dependent $(\mathrm{Y})$. Yang menjadi variabel dependent (terikat) dalam penelitian ini adalah kredit bermasalah.

\section{Teknik Analisis Data}

Teknik analisis data deskriptif yang dilakukan adalah sebagai berikut:

1. Melihat data mengenai Produk Domestik Regional Bruto (PDRB) Jawa Barat periode 2012 sampai 2017.

2. Melihat data Kredit Bermasalah Pada Bank Umum di Jawa Barat periode 2012 sampai 2017.

3. Melihat trend pertumbuhan Produk Domestik Regional Bruto (PDRB) Jawa Barat dan Kredit Bermasalah pada Bank Umum di Jawa Barat periode 2012-2017.

\section{Teknik Analisis Data Verifikatif}

\section{Uji Normalitas}

Melalui uji ini, sebuah data hasil penelitian dapat diketahui bentuk distribusi data tersebut, yaitu berdistribusi normal atau tidak normal.

Uji normalitas yang digunakan adalah dengan SPSS 23 for windows. Pengujian normalitas untuk data penelitian berdasarkan pada uji kolmogorov-smirnov.

Cara untuk mengetahui signifikan atau tidaknya hasil uji normalitas adalah dengan memerhatikan bilangan pada kolom signifikansi (Sig). Untuk menetapkan uji normalitas data, kriteria yang berlaku menurut Sumanto (2014:149) adalah sebagai berikut:

1. Tetapkan taraf signifikansinya misal a $=0,05$

2. Bandingkan $\rho$ dengan taraf signifikansi yang diperoleh.

3. Jika signifikansi yang diperoleh $>\alpha$, maka sampel berasal dari populasi yang berdistribusi normal.

4. Jika signifikansi yang diperoleh $<\alpha$, maka sampel bukan berasal dari populasi yang berdistribusi normal.

\section{Uji Linearitas Regresi}

Uji linearitas regresi bertujuan untuk mengetahui apakah dua variabel mempunyai hubungan yang linear atau tidak secara signifikan. Dalam penelitian ini pengujian linearitas dilakukan dengan menggunakan Tes For Linearity dengan taraf signifikasi 0,05 . Adapun menurut Sugiyono (2016:265), "Dua variabel dikatakan mempunyai hubungan linear bila signifikansi (linearity) kurang dari $0,05 "$.

\section{Analisis Regresi Linear Sederhana}

Menurut Sugiyono (2016:261), "regresi sederhana didasarkan pada hubungan fungsional ataupun kausal satu variabel independen dengan satu variabel dependen". Persamaan umum regresi linier sederhana menurut Sugiyono (2016:261) adalah:

$$
\hat{Y}=a+b X
$$

Dimana:

$\hat{Y}=$ subyek dalam variabel dependen yang diprediksikan.

$A=$ harga $Y$ ketika harga $X=0$ (harga konstan).

$\mathrm{B}=$ angka arah atau koefisien regresi, yang menunjukkan angka peningkatan ataupun penurunan variabel dependen yang didasarkan pada perubahan variabel independen. Bila (+) arah garis naik, dan bila (-) maka arah garis turun. 
$\mathrm{X}=$ subyek pada variabel independen yang mempunyai nilai tertentu.

\section{Analisis Koefisien Determinasi}

Analisis koefisien determinasi digunakan untuk mengetahui seberapa besar persentase pengaruh Produk Domestik Regional Bruto (PDRB) terhadap Kredit Bermasalah.

Menurut Hasan (2013:247), “jika koefisien korelasi dikuadratkan akan menjadi koefisien penentu (KP) atau koefisien determinasi, yang artinya penyebab perubahan pada variabel $Y$ yang datang dari variabel $X$, sebesar kuadrat koefisien korelasinya". Koefisien penentu dirumuskan:

$$
\mathrm{KP}=\mathrm{R}^{2}=(\mathrm{KK})^{2} \times 100 \%
$$

Sumber: (Hasan, 2013:247)

Keterangan:

$\mathrm{KP}=$ koefisien determinasi

$\mathrm{R} \quad=$ koefisien korelasi

$\mathrm{KK}=$ koefisien korelasi

\section{Pengujian Hipotesis}

Menurut Wijaya

(2013:12), "hipotesis disamakan dengan dugaan secara logis hubungan antara 2 (dua) variabel atau lebih yang ditunjukkan dalam pernyataan yang di uji kebenarannya". Adapun langkah-langkah untuk pengujian hipotesis menurut Sugiyono (2016:89) adalah sebagai berikut:

1. Pengujian Hipotesis Statistik adalah:

Penentuan hipotesis statistiknya $\mathrm{H}_{0}: \rho=0$ Berarti Produk Domestik Regional Bruto (PDRB) tidak berpengaruh terhadap Kredit Bermasalah.

Ha : $\rho \neq 0$ Berarti Produk Domestik Regional Bruto (PDRB) berpengaruh terhadap Kredit Bermasalah.

2. Penentuan Statistik Uji
Pengujian hipotesis dilakukan dengan menggunakan metode statistik berupa uji t dengan uji dua pihak.

a. $\mathrm{H}_{0}$ diterima jika $-\mathrm{t}$ tabel $<\mathrm{t}$ hitung $<\mathrm{t}$ tabel

b. Ho ditolak jika $-\mathrm{t}$ hitung $<-\mathrm{t}$ tabel atau $\mathrm{t}$ hitung $>\mathrm{t}$ tabel

Dari daftar distribusi $t$ dengan $\alpha=0.05$ dan $\mathrm{dk}=6-2$ diperoleh $\mathrm{t}$ tabel $=2,776$

\section{HASIL DAN PEMBAHASAN}

\section{Analisis Produk Domestik Regional Bruto}

Berikut penulis sajikan grafik data Produk Domestik Regional Bruto (PDRB) Jawa Barat periode 2012-2017 serta grafik pertumbuhan Produk Domestik Regional Bruto (PDRB) Jawa Barat periode 2012-2017.

Gambar 1. Produk Domestik Regional Bruto Jawa Barat Periode 2012-2017 (Dalam milyar $\mathrm{Rp})$

\begin{tabular}{|c|c|}
\hline \multicolumn{2}{|c|}{$\begin{array}{c}\text { Produk Domestik Regional Bruto } \\
\text { Jawa Barat }\end{array}$} \\
\hline \multirow{4}{*}{$\begin{array}{l}2.000 .000 .00 \\
1.500 .000 .00 \\
1.000 .000 .00\end{array}$} & 1.786 .092 .3 \\
\hline & $1,524,974.8 \quad 8$ \\
\hline & $\begin{array}{ccc}1.258 .989 .3 & 30 & 1,652,757.8 \\
3 & 1.385 .825 .0 & 2\end{array}$ \\
\hline & $1.128 .245 .6 \quad 8$ \\
\hline 500.000 .00 & 8 \\
\hline- & 201220132014201520162017 \\
\hline
\end{tabular}

Gambar 2. Pertumbuhan PDRB Jawa Barat Periode 2012-2017

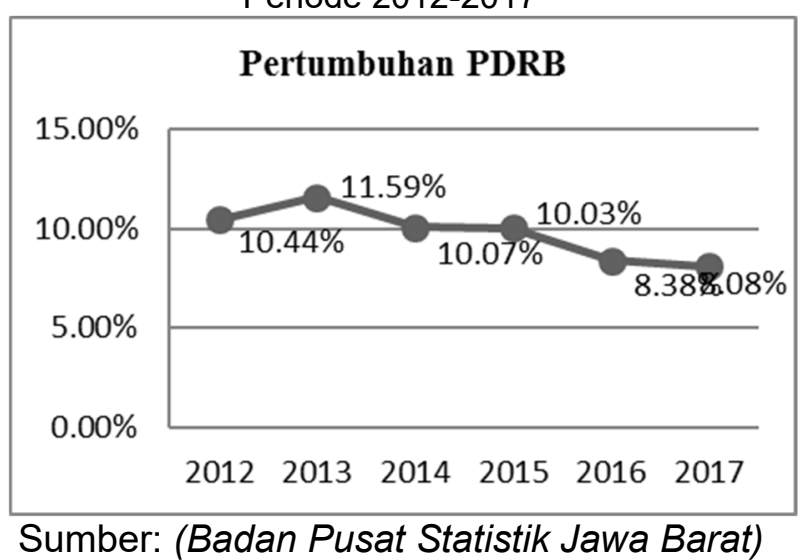


Produk Domestik Regional Bruto (PDRB) Jawa Barat periode 2012-2017 secara total cenderung naik. Hal ini didorong oleh meningkatnya distribusi dari beberapa komponen PDRB terhadap total PDRB, seperti konsumsi rumah tangga, pemerintah, dan ekspor . Namun, dengan meningkatnya Produk Domestik Regional Bruto (PDRB) secara total tidak turut serta meningkatkan pertumbuhan PDRB Jawa Barat.

Berdasarkan data pada grafik 4.2 diatas menunjukkan bahwa pertumbuhan PDRB Jawa Barat periode 2012-2017 cenderung melambat. Kenaikan pertumbuhan PDRB terjadi pada tahun 2013 sebesar $11.59 \%$, hal ini didorong oleh peningkatan kinerja perekonomian Jawa Barat dengan meningkatnya pertumbuhan konsumsi rumah tangga dan LNPRT yaitu Pengeluaran konsumsi Lembaga Non Profit yang melayani Rumah Tangga yakni berbagai pengeluaran oleh lembaga untuk pengadaan barang dan jasa, yang secara prinsip mempunyai fungsi dalam melayani rumah tangga.

\section{Sedangkan} melambatnya pertumbuhan PDRB setelah tahun 2013 disebabkan oleh terjadinya perlambatan pertumbuhan konsumsi rumah tangga yang merupakan komponen dengan pangsa terbesar pada PDRB Jawa Barat serta melambatnya pertumbuhan konsumsi pemerintah, dan Pembentukan Modal Tetap Bruto (PMTB).

\section{Kredit Bermasalah}

Untuk mengetahui pertumbuhan Kredit Bermasalah pada Bank Umum di Jawa Barat periode 2012-2017 maka penulis sajikan data dalam bentuk grafik sebagai berikut:
Gambar 3. Pertumbuhan Kredit Bermasalah pada Bank Umum di Jawa Barat Periode 20122017

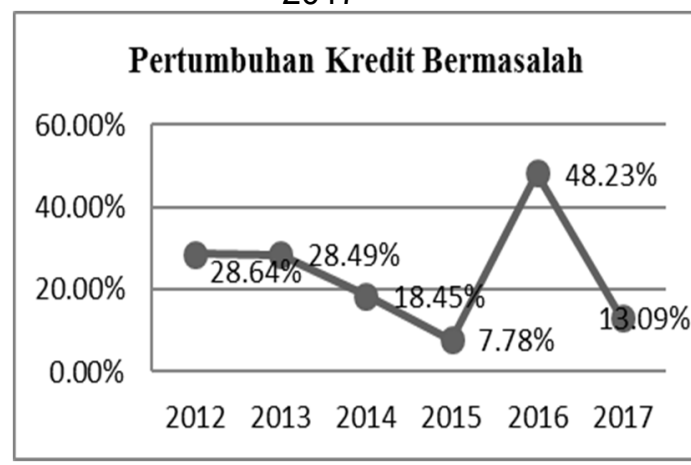

Sumber: (Otoritas Jasa Keuangan)

Kredit Bermasalah Pada Bank Umum di Jawa Barat periode 2012-2017 secara total cenderung mengalami kenaikan. Hal tersebut berbeda dengan pertumbuhan kredit bermasalah pada Bank Umum di Jawa Barat periode 20122017 yang cenderung menurun seperti yang terlihat pada grafik 4.4 diatas. Menurunnya pertumbuhan kredit bermasalah pada periode 2012-2017 dikarenakan adanya perlambatan pertumbuhan kredit pada bank umum di Jawa Barat pada periode tersebut serta lebih tingginya tingkat kehati-hatian bank dalam menyalurkan kredit kepada nasabah.

Kenaikan pertumbuhan kredit bermasalah yang cukup tinggi terjadi pada tahun 2016 sebesar 48,23\%. Menurut Kajian Ekonomi Regional Provinsi Jawa Barat (Bank Indonesia, 2016:102) dari sisi lapangan usaha terjadi kenaikan risiko kredit pada beberapa sektor usaha di Jawa Barat, yaitu sektor pertambangan, industri pengolahan, listrik, gas, dan air, transportasi, real estate, usaha persewaan, dan jasa perusahaan. Sehingga hal tersebut turut mendorong terjadinya kenaikan kredit bermasalah pada bank umum di Jawa Barat pada tahun 2016. 
Sedangkan pada tahun 2017 pertumbuhan kredit bermasalah pada bank umum di Jawa Barat kembali menurun, menurut Kajian Ekonomi Regional Provinsi Jawa Barat (Bank Indonesia, 2018:5) intermediasi perbankan terpantau dalam kondisi yang cukup baik, tercermin dari risiko kredit yang menurun meskipun pertumbuhan penyaluran kredit melambat. Maka, dapat disimpulkan bahwa pada tahun 2017 pertumbuhan kredit di Jawa Barat turun, sehingga pertumbuhan kredit bermasalah pada bank umum di Jawa Barat tahun 2017 menurun.

\section{Hasil Penelitian dan Pembahasan Verifikatif}

\section{Uji Normalitas}

Berdasarkan Uji Normalitas OneSample Kolmogorov-Smirnov Test diketahui nilai signifikansi 0,816 > 0,05 maka dapat disimpulkan bahwa nilai residual berdistribusi normal.

\section{Uji Linearitas}

Berdasarkan hasil Uji Linearitas menunjukkan bahwa nilai signifikansi sebesar 0,001. Dua variabel dikatakan mempunyai hubungan linear bila signifikansi (linearity) kurang dari 0,05 (Sugiyono, 2016:265). Berdasarkan hal tersebut $0,001<0,05$ sehingga dapat dikatakan bahwa Produk Domestik Regional Bruto (PDRB) memiliki hubungan linear terhadap Kredit Bermasalah.

\section{Analisis Regresi Linear Sederhana}

Berdasarkan hasil dari pengolahan SPSS, maka didapatkan hasil, bahwa nilai a sebesar $-11246,036$ dan nilai $b$ sebesar 0,014. Jadi apabila dimasukan kedalam persamaan menjadi sebagai berikut:

$$
Y=a+b X
$$

$$
Y=-11246,036+0,014 X
$$

Keterangan :

$Y=$ Kredit Bermasalah

$X=$ PDRB

Dari persamaan regresi di atas dapat diketahui bahwa variabel $X$ (PDRB) berpengaruh positif terhadap variabel $Y$ (Kredit Bermasalah). Ini berarti, bahwa pengaruh dari Produk Domestik Regional Bruto (PDRB) terhadap Kredit Bermasalah memiliki arah yang positif. Setiap kenaikan 1 PDRB maka akan mengurangi 0,014 kredit bermasalah.

\section{Analisis Determinasi}

Analisis koefisien determinasi dilakukan untuk mengetahui seberapa besar pengaruh Produk Domestik Regional Bruto (PDRB) terhadap Kredit Bermasalah pada Bank Umum di Jawa Barat. Adapun rumus yang digunakan untuk menghitung koefisien determinasi yaitu:

$$
K P=R^{2}=(K K)^{2} \times 100 \%
$$

Berdasarkan hasil pengolahan SPSS Koefisien Korelasi dan Determinasi menunjukkan besarnya $R$ Square yaitu 0,938 . $R$ Square ini disebut juga koefisien determinasi. Nilai tersebut didapat dari pengkuadratan koefisien korelasi $(R)$ yaitu $0,968^{2}=0,938$. Jadi dapat dikatakan pengaruh Produk Domestik Regional Bruto (PDRB) terhadap Kredit Bermasalah yaitu sebesar 0,938 atau sebesar $93,8 \%$. sisanya sebesar $6,2 \%$ dipengaruhi oleh faktor lain yang penulis tidak teliti.

\section{Uji Hipotesis}

Berdasarkan hasil penelitian SPSS pada tabel coefficient di dalam kolom t diketahui bahwa nilai $t$ hitung adalah 7,776 sedangkan $t$ tabel yaitu 2,776 . Nilai $t$ tabel diperoleh pada 
taraf nyata yaitu pada $\alpha=0,05 \mathrm{dk}=$ n-2. Dari hasil perhitungan diperoleh bahwa $\mathrm{t}$ hitung $>\mathrm{t}$ tabel yaitu $7,776>2,776$ dan atau melihat signifikansi sebesar $0,001<0,05$ maka Ho ditolak dan Ha diterima, jadi dapat dinyatakan bahwa Produk Domestik Regional Bruto (PDRB) berpengaruh positif signifikan terhadap Kredit Bermasalah pada Bank Umum di Jawa Barat.

Berdasarkan hasil penelitian menunjukkan bahwa PDRB berpengaruh positif signifikan terhadap Kredit Bermasalah pada Bank Umum di Jawa Barat. Salah satu penyebabnya dikarenakan besarnya penyaluran kredit pada bank umum di Jawa Barat, dan melebihi pertumbuhan Produk Domestik Regional Bruto (PDRB) Jawa Barat.

Hasil penelitian ini memperkuat penelitian yang dilakukan oleh Aga Fajar Arifandi, Universitas Diponegoro Semarang tahun 2017 dengan judul penelitian "Analisis Pengaruh Bank Size, PDRB, CAR, NIM, LDR, dan BOPO Terhadap Non Performing Loans (NPL) Bank Pembangunan Daerah di Indonesia". Dimana hasil penelitian tersebut menunjukkan bahwa PDRB berpengaruh positif signifikan terhadap NPL.

\section{PENUTUP}

\section{Simpulan}

Berdasarkan hasil penelitian dan pembahasan yang telah dipaparkan, maka penulis dapat menyimpulkan:

1. Produk Domestik Regional Bruto (PDRB) Jawa Barat periode 20122017 cenderung mengalami kenaikan.
2. Kredit Bermasalah pada Bank Umum di Jawa Barat periode 2012-2017 cenderung mengalami kenaikan.

3. Produk Domestik Regional Bruto (PDRB) berpengaruh positif signifikan terhadap Kredit Bermasalah pada Bank Umum di Jawa Barat periode 2012-2017.

\section{Saran}

1. Pemerintah harus meningkatkan pertumbuhan Produk Domestik Regional Bruto (PDRB) di Jawa Barat. Menurut Sukirno (2010:429), "faktorfaktor yang menentukan pertumbuhan ekonomi diantaranya, tanah dan kekayaan alam, jumlah dan mutu dari penduduk dan tenaga kerja, barangbarang modal dan tingkat teknologi, serta sistem sosial dan sikap masyarakat". Berdasarkan pernyataan tersebut, maka pemerintah dapat melakukan upaya peningkatan pertumbuhan Produk Domestik Regional Bruto (PDRB) di Jawa Barat melalui sektor/sub sektor lapangan usaha yang berada di Jawa Barat, terutama yang menjadi penopang utama perekonomian Jawa Barat yaitu industri pengolahan, pedagang besareceran dan reparasi, serta pertanian, kehutanan, dan perikanan, dengan memanfaatkan potensi sumber daya alam, sumber daya manusia, serta teknologi secara optimal untuk meningkatkan kualitas serta mutu produk yang dihasilkan. Sehingga konsumsi rumah tangga, LNPRT, pemerintah, maupun komponenkomponen PDRB yang lainnya akan meningkat.

2. Pihak perbankan harus menurunkan kredit bermasalah dengan lebih berhati-hati dalam menyalurkan kredit. Sebaiknya sebelum memutuskan suatu persetujuan kredit, pihak perbankan melakukan analisa kredit terhadap calon debiturnya secara 
menyeluruh, benar, dan teliti sesuai dengan prinsip perkreditan agar tidak terjadi kesalahan dalam pemberian kredit serta untuk memperkecil adanya risiko kredit yang akan dihadapi oleh pihak perbankan.

\section{DAFTAR PUSTAKA}

Abdurrahman Maman, Sambas Ali Muhidin, dan Ating Somantri. 2011. Dasar-Dasar Metode Statistika Untuk Penelitian. Bandung: CV Pustaka Setia.

Badan Pusat Statistik Kota Tasikmalaya. 2018. Produk Domestik Regional Bruto Kota Tasikmalaya Menurut Pengeluaran Tahun 2013-2017. Tasikmalaya: Badan Pusat Statistik Kota Tasikmalaya.

Badan Pusat Statistik Provinsi Jawa Barat. 2017. Produk Domestik Regional Bruto Jawa Barat Menurut Pengeluaran Tahun 2012-2016. Bandung: Badan Pusat Statistik Provinsi Jawa Barat.

. 2018. Produk Domestik Regional Bruto Jawa Barat Menurut Pengeluaran Tahun 2013-2017. Bandung: Badan Pusat Statistik Provinsi Jawa Barat.

Bank Indonesia Provinsi Jawa Barat. 2013. Kajian Ekonomi Regional Provinsi Jawa Barat. Bandung: Bank Indonesia Provinsi Jawa Barat.

2017. Kajian Ekonomi Regional Provinsi Jawa Barat. Bandung: Bank Indonesia Provinsi Jawa Barat.
2018. Kajian Ekonomi Regional Provinsi Jawa Barat. Bandung: Bank Indonesia Provinsi Jawa Barat.

Fahmi, Irham. 2011. Manajemen Risiko. Bandung: Alfabeta.

2014. Manajemen Perkreditan. Bandung: Alfabeta.

2014.
Perbankan Teori \&
Bandung: Alfabeta.

Hasan, Iqbal. 2013. Pokok-Pokok Materi Statistik 1 (Statistik Deskriptif). Jakarta: PT Bumi Aksara.

Ikatan Bankir Indonesia. 2014. Mengelola Kredit Secara Sehat. Jakarta: PT Gramedia Pustaka Utama. 2015. Bisnis Kredit Perbankan. Jakarta: PT Gramedia Pustaka Utama.

Kasmir. 2013. Dasar-Dasar Perbankan. Jakarta: PT Raja Grafindo Persada.

Kuncoro, Mudrajad \& Suhardjono. 2002. Manajemen Perbankan Teori dan Aplikasi. Yogyakarta: BPFE.

Misbahuddin dan Iqbal Hasan. 2014. Analisis Data Penelitian Dengan Statistik. Jakarta: PT Bumi Aksara.

Mulyati, Etty. 2016. Kredit Perbankan (Aspek Hukum dan Pengembangan Usaha Mikro Kecil Dalam Pembangunan Perekonomian Indonesia). Bandung: PT Refika aditama. 
Nazir, Mohammad. 2011. Metode Penelitian. Bogor: Ghalia Indonesia.

Neolaka, Amos. $2014 . \quad$ Metode Penelitian dan Statistik. Bandung: PT Remaja Rosdakarya.

Otoritas Jasa Keuangan. 2018. Statistik Perbankan Indonesia Volume 16 No. 01. Jakarta: Otoritas Jasa Keuangan .

Putong, Iskandar. 2013. Pengantar Mikro dan Makro. Jakarta: Mitra Wacana Media.

Samuelson P.A \& Nordhaus W.D. 2004. IImu Makro Ekonomi. Jakarta: PT. Media Global Edukasi.

Sangadji, Etta Mamang dan Sopiah. 2010. Metodologi Penelitian Pendekatan Praktis Dalam Penelitian. Yogyakarta: CV Andi Offset.

Siregar, Syofian. 2017. Statistik Parametrik Untuk Penelitian Kuantitatif. Jakarta: PT Bumi Aksara.

Siswanto, sutojo. 2008. Menangani Kredit Bermasalah (Handling The Problem Loan). Jakarta: PT Damar Mulia Pustaka.

Sjafrizal. $2014 . \quad P e r e n c a n a a n$ Pembangunan Daerah Dalam Era Otonom/Sjafrizal. Jakarta: Rajawali Pers.

Sugiyono. 2013. Metode Penelitian Bisnis. Bandung: Alfabeta.

2016. Statistika Untuk Penelitian. Bandung: Alfabeta.
Sujarweni, V. Wirana. 2015. Metedologi Penelitian - Bisnis \& Ekonomi. Yogyakarta: Pustaka Baru Press.

Sukirno, Sadono. 2010. Makro Ekonomi Teori Pengantar. Jakarta: PT Raja Grafindo Persada.

Suliyanto. 2018. Metode Penelitian Bisnis. Yogyakarta: CV Andi Offset.

Sumanto. 2014. Statistika Terapan. Yogyakarta: CAPS (Center of Academic Publishing Service).

Taswan. 2010. Manajemen Perbankan. Yogyakarta: UPP STIM YKPN.

Wijaya, Tony. 2013. Metodologi Penelitian Ekonomi dan Bisnis; Teori dan Praktik. Yogyakarta: Graha IImu.

\section{Sumber Karya IImiah:}

Arifandi, Aga Fajar. 2017. Analisis Pengaruh Bank Size, PDRB, CAR, NIM, LDR, dan BOPO Terhadap Non Performing Loans (NPL) Bank Pembangunan Daerah di Indonesia. Skripsi. Universitas Diponegoro Semarang.

Firmansyah, Irman. 2014. Determinant of Non Performing Loan: The Case of Islamic Bank in Indonesia. Jurnal. Universitas Siliwangi.

Nasution, Marihot dan Doddy Setiawan. 2007. Pengaruh Corporate Governance Terhadap Manajemen Laba di Industri Perbankan Indonesia. Simposium Nasional Akuntansi $\mathrm{X}$ : Unhas Makassar. 
$\begin{array}{crr}\text { Rahmawulan, } & \text { Yunis. } & 2008 . \\ \text { Perbandingan } & \text { Faktor } & \text { Penyebab }\end{array}$ Timbulnya NPL dan NPF Pada Perbankan Konvensional dan Syariah di Indonesia. Tesis, Program Pasca Sarjana: Universitas Indonesia.

Tabrizi, Ahmad. 2014. Analisis Pengaruh Variabel Makro Terhadap Non Performing Financing (NPF) Bank Umum Syariah di Indonesia. Skripsi. Universitas Islam Negeri Syarif Hidayatullah Jakarta.

\author{
Sumber Dokumen: \\ Peraturan Bank Indonesia Nomor \\ 14/15/PBI/2012 Tentang Penilaian \\ Kualitas Aset Bank Umum. \\ Peraturan Bank Indonesia Nomor \\ 15/12/PBI/ $2013 \quad$ Tentang \\ Kewajiban Penyediaan Modal \\ Minimum Bank Umum.
Peraturan Otoritas Jasa Keuangan Nomor 29/POJK.05/2014 Tentang Penyelenggaraan Usaha Perusahaan Pembiayaan.

Undang-Undang No. 10 Tahun 1998 